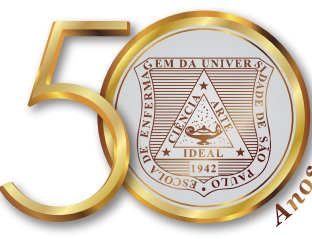

\title{
Cultural adaptation and content validation of the Single-Question for screening alcohol abuse
}

\author{
Adaptação cultural e validação de conteúdo da Questão Chave para rastreamento do uso \\ abusivo de álcool \\ Adaptación cultural y validación de contenido de la Single-Question para el rastreo del uso \\ abusivo de alcohol
}

Marjorie Ester Dias Maciel', Divane de Vargas ${ }^{1}$

How to cite this article:

Maciel MED, Vargas D. Cultural adaptation and content validation of the Single-Question for screening alcohol abuse. Rev Esc Enferm USP. 2017:e03292. DOI: http://dx.doi.org/10.1590/S1980-220X2016048703292

${ }^{1}$ Universidade de São Paulo, Escola de Enfermagem, Departamento de Enfermagem Materno Infantil e

Psiquiátrica, São Paulo, SP, Brazil.

\begin{abstract}
Objective: Describing the stages of translation, cultural adaptation and content validation of the Single-Question into Brazilian Portuguese, which will be named Questão Chave. Method: This study is a cultural adaptation. The instrument was translated into Portuguese as two independent versions which led to a synthesis of translations (S1), and later to the synthesis S2, which was then submitted to evaluation by a Committee of Expert Judges in the area of alcohol use and instrument validation. The Content Validity Index and Kappa agreement coefficient were calculated from this evaluation. Results: The judges evaluated the Questão Chave regarding the clarity of the sentence and aspects related to the quality of the translation (cultural adaptation, preservation of original meaning and correct use of technical terms). The Content Validity Index was 1 for clarity of sentence and correct use of technical terms, and 0.8 for adaptation and preservation of the original meaning. The Kappa index for concordance among the judges was 0.83 . After an adjustment proposed by the judges, the $\mathrm{S} 3$ version was originated. Conclusion: The Ouestão Chave had its content validity confirmed, which supports future studies that aim for its application in the target population to verify their psychometric properties.
\end{abstract}

DESCRIPTORS

Alcohol-Related Disorders; Cross-Cultural Comparison; Validation Studies; Reproducibility of Results. 


\section{INTRODUCTION}

Risky and harmful alcohol consumption is currently considered a relevant issue for global public health. According to the World Health Organization (WHO) ${ }^{(1)}$, the excessive use of alcohol is responsible for 2.5 million deaths worldwide. In Brazil, data from the National Health Surveillance indicate a prevalence of $13.7 \%$ alcohol abuse by the Brazilian population over 18 years of age ${ }^{(2)}$.

Data from the Global Status Report from 2014 show that alcohol is responsible for some type of morbidity among $8.2 \%$ of males and $3.2 \%$ of females in Brazil ${ }^{(3)}$. In addition, it entails an annual loss of $\$ 4$ billion to the country's public treasury ${ }^{(4)}$. Thus, these percentages point to the need to propose and implement strategies aimed at preventing and reducing alcohol abuse among the Brazilian population.

Among these strategies, early screening and brief intervention for detected cases such as risk and harmful use of alcohol are measures that can have a positive impact on reducing alcohol-related harm and health problems.

However, despite these measures being effective, their low cost and easy implementation, they are not routinely employed by the Brazilian Primary Health Care service $(\mathrm{PHC})^{(5)}$.

The suggested reasons for this situation are a lack of professional knowledge of the problem ${ }^{(5)}$, a lack of professional preparation and a lack of time in the work schedule ${ }^{(6-7)}$.

Regarding screening instruments for the risky use of alcohol in Brazil, a large number have been validated for use in our culture in recent decades ${ }^{(8-13)}$ with proven effectiveness; however, most of them present some characteristics which hinder their use in Primary Health Care services.

Among these characteristics the following may be highlighted: the identification of only later phases of disorders related to alcohol use ${ }^{(8)}$ in the case of alcohol dependence, the excessive number of questions in the instrument ${ }^{(9-10,13)}$, validation for use in specific groups of users of Primary Health Care ${ }^{(11,13)}$, the complexity of interpreting the scores obtained using the questionnaire ${ }^{(12)}$, and little concern regarding gender differences ${ }^{(8,10)}$.

Considering the characteristics of the instruments available for use in Brazil which end up limiting their use in the PHC service routine, we highlight the need to validate or develop practical, easy-to-use and low-cost screening instruments that do not require specific training for their application. In 2005, the National Institute on Alcohol Abuse and Alcoholism (NIAAA) proposed the use of a single screening question in $\mathrm{PHC}$ services ${ }^{(7,14)}$ for the risky/ harmful use of alcohol called the Single-Question (SQ) in order to address these difficulties. It has been used in PHC services in the US and has shown good results; however, the Single-Question (questão única in free translation) is not yet translated into Portuguese and culturally adapted for use in $\mathrm{Brazil}^{(7)}$.

Therefore, this article aims to describe the translation, cultural adaptation and validation stages of the SQ content for Brazilian Portuguese, and which will be named Questão Chave in Portuguese.

\section{Single-QueSTION AS A SCREenING TOOL FOR HARMFUL}

\section{ALCOHOL USE}

The idea of using a single question for the screening of unhealthy alcohol use was first put into practice at the end of the 1990s, presented as "Have you ever had drinking problem?" translated freely into Portuguese as "Vocêjá teve problemas com bebidas alcoolicas?". This question used the diagnostic criteria of DSM-III for alcohol-related disorders as the gold standard, with specificity of 0.573 and sensitivity of $0.879^{(15)}$. Later, a study ${ }^{(16)}$ involving 1,435 people used the same question with some modifications: "On any single occasion during the past 3 months, have you had more than 5 drinks containing alcohol?" "Em uma única ocasião, nos 3 últimos meses, você ingeriu mais que 5 doses de bebida contendo álcool?" according to the free translation into Portuguese, and which was referred to as the Single-Question (SQ) for the first time. In this study ${ }^{(16)}$, the AUDIT test was applied in conjunction with the SQ and considered as the gold standard for comparison. The results showed that the SQ had a positive predictive value of $74 \%$, a negative predictive value of $88 \%$, sensitivity of $62 \%$ and specificity of $93 \%$ for the risk of drinking and for other disorders related to alcohol intake, and that the SQ tracked the same individuals as the AUDIT regarding hazardous/harmful use.

However, in order to improve the understanding of the question and considering the physiological differences between the genders, there was a need to reformulate the question and introduce different dose values for men and for women. Thus, the reformulated SQ was: "When was the last time you had more than $X$ drinks in 1 day?", translated freely as: "Quando foi a última vez que você ingeriu mais que $X$ doses de bebida alcoólica em um dia?", where $\mathrm{X}=4$ for women and $\mathrm{X}=5$ for men. The sensitivity and specificity of this version were both $86 \%{ }^{(17)}$.

In 2005, the NIAAA recommended the use of the SQ to screen for hazardous/harmful use of alcohol as routine for those patients who respond positively to the use of alcoholic beverages. The version presented by the NIAAA on that occasion was: "How many times in the past year you had $X$ or more drinks in a day?" freely translated into Portuguse as, "Quantas vezes no ano passado você bebeu $X$ ou mais doses de bebida alcoólica em um dia?", where $\mathrm{X}=4$ for women and $\mathrm{X}=5$ for men, and the risk/harmful use of alcohol is considered positive when the individual responds one or more times ${ }^{(14)}$.

This version proposed by the NIAA ${ }^{(7)}$ was validated for American PHC services in 2009, using a sample of 286 individuals of both genders who were recruited in the waiting room of PHC services. The gold standard used was the AUDIT and its version, AUDIT-C. The results showed that the SQ obtained $81.8 \%$ sensitivity and $79.3 \%$ specificity for detection of harmful use; regarding the presence of current disorders related to alcohol use, the SQ was more sensitive (87.9\%) but less specific (66.8\%) than the AUDIT, with similar results when compared to the AUDIT-C, which ensured the suitability of the SQ proposed by the NIAAA for use in American PHC services ${ }^{(7)}$.

The translated and validated version of the SQ into the Italian language was applied to a sample of surgical patients 
in Cagliari, Italy, also using the AUDIT as the gold standard. The results showed that the positive predictive value was 0.78 and the negative value was 0.36 when compared with the AUDIT, also proving the instrument's validity for that language ${ }^{(18)}$.

The study results conducted so far using the SQ suggest that it is a useful tool for detecting/screening risky alcohol use in comparison to the AUDIT, a more widely used instrument in PHC services worldwide nowadays ${ }^{(19)}$, and that it has performed well not only in its original language, but also in a language which it has been translated into ${ }^{(18)}$. For this reason, we consider important to carry out its translation and cultural adaptation to Brazilian Portuguese.

\section{METHOD}

This is a cultural adaptation and instrument content validation study concerning the translation, adaptation and validation process of a sentence that seeks the conceptual equivalence between the original sentence and that translated into another language ${ }^{(20)}$. The study was approved by the Ethics Committee of the Nursing School of the Univesidade de São Paulo under the number 772.025.

The following steps were used for the process of adaptation and content validation: 1) Two independent translations; 2) Synthesis of the translations; 3) Back translation or retro-translation phase (translation of the version back to English); 4) Analysis by a Committee of Specialist Judges; 5) Adjustments to the final version; and 6) Pre-test with people eligible for the target population ${ }^{(21)}$.

Firstly, the original version was translated into Portuguese by two native English speakers, fluent in the Portuguese language. As recommended by specialists in the instrument

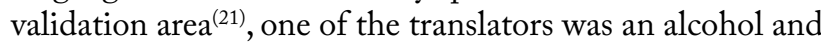
drug researcher and was fully aware of the purpose of the study, while the other was not a specialist in the field and was unaware of the purpose of the study. Thus, two independent translations (T1 and T2) were made, in which each translator was free to make the observations they deemed necessary. This phase resulted in two translations which were synthesized by the authors; the synthesized version was called S1.

The back translation of S1, meaning the translation of S1 into English was performed by two native translators of English; both were specialists in translations of scientific articles with no expertise in the area of the instrument and were not aware of the translation performed by their peer. These translations resulted in versions B1 and B2. The purpose of this step was to verify if the translation of a sentence from its source language into the target language had its meaning preserved, which means to identify whether there was semantic equivalence, thus guaranteeing preservation of the original meaning of the translated item ${ }^{(22-23)}$.

For B1 and B2, both back-translations were compared and examined for discrepancies. Based on the translators' observations, the authors identified the need to make some changes to achieve idiomatic equivalence. Thus, choosing to replace the expression "last year/ano passado" by its synonym "in the last 12 months/nos últimos 12 meses" considering that the term "past year" could induce the interviewee's response leading them to only consider the past year and not the current year while reporting their consumption of alcoholic beverages. Moreover, the expression "last 12 months" refers to the idea of including the current time, as it does with the Portuguese version of the AUDIT, which also uses the term "in the last 12 months" rather than the "last year" of the original version. This gave rise to a new synthesis called S2, which was then submitted for analysis by a Committee of Specialist Judges.

The Committee of Specialist Judges had the purpose of verifying whether the process of translation and back-translation reached semantic, conceptual and idiomatic equivalence; in other words, whether the situations mentioned or portrayed are culturally relevant or understandable to the target population, or whether the original meaning was lost during the translation process. Thus, an adaptation to Brazilian Portuguese is in fact guaranteed. The submission of the translation for the analysis of this Committee is characterized as the second stage of the semantic validation process $^{(22)}$.

In this study, it was up to the Judges' Committee to select which version of the Single-Question would become the ideal Questão Chave to be used among the Brazilian population. The criteria adopted to compose the body of judges were: being a health professional and an alcohol and drug expert with publications in the area or in validation of psychometric instruments, having a doctorate degree and being fluent in the English language.

Considering that the minimum composition recommended by the specialists for the composition of a judges' committee is of at least three components ${ }^{(22)}, 13$ researchers were selected and invited to perform this task. Contact was made through an invitation letter sent via e-mail. Of those, five responded by accepting the invitation.

The panel of judges consisted of two psychologists, two physicians and one nurse, all of whom held a doctorate degree and met the desired inclusion criteria. One of the judges was a foreigner with fluency in the Portuguese language who participated in the validation process of the SQ in its original context.

The five researchers who accepted to participate in the Committee received the documents for analysis by e-mail, which contained the two first translations (T1 and T2), the synthesis of T1 and T2 (S1), the two back-translation versions and the final synthesis of S2, along with the syntheses. The judges also received an illustration containing the amount referring to a standard dose of each alcoholic beverage in the Brazilian context, and lastly they received a questionnaire to evaluate the content of the $\mathrm{S} 2$ version regarding clarity of the sentence. In this questionnaire, the judges evaluated clarity on a scale of 1 to 4 points, with 1 meaning that the sentence was not clear and 4 that the sentence was fully clear. The judges were also asked to evaluate the translation quality regarding the adaptation and preservation of the meaning and the terms used in S2 by assigning a score on a scale from 1 to 3 points in which 1 meant that the question did not meet the criteria, 2 meant it partially met it, and 3 meant that it fully met the criteria. 
A space was provided at the end of the questionnaire for additional considerations or observations that the judges considered relevant.

In order to verify to what extent the Questão Chave represented the content of interest, the Content Validity Index (CVI) was calculated. This index evaluates the judges' agreement as to the representativeness of the content in the analyzed sentence ${ }^{(21-23)}$. The minimum acceptable pre-set CVI parameter is 0.80 , and indicates equivalence of content; lower values indicate that the analyzed aspect is unclear or not adequately translated and adapted, and that the item requires reformulating ${ }^{(22)}$.

The following formula was used to calculate the $\mathrm{CVI}^{(22)}$ :

$$
\mathrm{CVI}=\frac{\text { Total of scores } 3 \text { or } 4 \text { given by the Judges }}{\text { Overall total of the scores }}
$$

The Kappa coefficient was calculated to assess whether the observed concordance among Judges did not occur at random and to ensure that such agreement was actually assigned to the content properties of the question ${ }^{(24)}$. The Kappa coefficient represents the ratio of the proportion of times the judges agree (corrected by agreement due to chance) with the maximum proportion of times judges could agree (corrected by agreement due to chance). Kappa values can range from -1 (total absence of agreement) to 1 (total agreement). Therefore, the ideal value would be 1 or a variation from 1 to 0.8 being considered an ideal agreement; from 0.79 to 0.6 would correspond to substantial agreement; from 0.59 to 0.4 being moderate agreement; from 0.39 to 0.2 weak agreement; from 0.19 to 0 poor agreement; and < 0 no agreement ${ }^{(24)}$.

The calculation of the Kappa coefficient is given by the following formula ${ }^{(24)}$ :

$$
\mathrm{K}=\frac{\sum f a-\sum f e}{\mathrm{~N}-\Sigma f e}
$$

In which $f_{\mathrm{a}}$ represents the sum of the observed agreement rate and $f_{\mathrm{e}}$ is the sum of the proportion of agreement expected by chance.

After evaluation by the judges, the next step was the pre-test which corresponds to applying the instrument to 30 people who use $\mathrm{PHC}$ services, individuals that compose the target population for the instrument in order to evaluate the degree of understanding of the question. These individuals were approached while waiting for care in a Basic Health Unit located in the city of São Paulo.

\section{RESULTS}

The two independent translations were not conflicting; T1 was: "No ano passado quantas vezes você bebeu $X$ ou mais bebidas alcoólicas em um dia?" and T2 was: "Quantas vezes no ano passado você bebeu X ou mais doses de bebida alcoólica em um dia?" The $\mathrm{S} 1$ synthesis was made considering the similarity between both translations, with a partial version presented as: "Quantas vezes no ano passado você ingeriu X ou mais doses de bebida alcoólica?"

In search of linguistic and cultural equivalence, we chose to replace the expression "in the past year/no ano passado" freely translated into Portuguese by its synonym "in the last
12 months/nos últimos 12 meses". This adequacy was carried out considering that the term "in the past year" could induce the respondents to only consider the previous year, not considering the current year when reporting their consumption of alcoholic beverages, while the expression "in the last 12 months" refers to the idea of including the current time. These adaptations are in line with the Brazilian version of the AUDIT, which also uses the term "in the last 12 months" instead of the expression "last year" from the original version ${ }^{(25)}$.

After this adjustment, the S2 version of the SQ was configured as follows: "Quantas vezes nos últimos 12 meses você ingeriu X ou mais doses de bebida alcoólica em um dia?” This version was then submitted to the Judges Committee for evaluation.

The judges' evaluation of the S2 version was quantified and it is presented in Tables 1 and 2. One of the judges suggested that the verb ingest/ingerir should be replaced by the verb drink/beber, since according to the evaluator's observations this verb change would facilitate better understanding of the question by the layers of the target population with lower education. This suggestion was accepted by the authors, and it resulted on the emergence of $\mathrm{S} 3$ version of the SQ: "Quantas vezes nos últimos 12 meses você bebeu $X$ (5 se for homem ou 4 se for mulher) ou mais doses de bebida alcoólica em um dia?"

Evaluations on the clarity of the Questão chave as well as the maximum possible score and that obtained by the sum of the answers of the judges on this aspect are shown in Table 1.

Table 1 - Evaluation of Specialist Judges regarding the translation clarity of the Questão Chave - São Paulo, São Paulo, Brazil, 2016.

\begin{tabular}{cccccccc}
\hline Judges & J1 & J2 & J3 & J4 & J5 & Maximum score & Obtained score \\
\hline Clarity & 4 & 4 & 4 & 4 & 4 & 20 & 20 \\
\hline
\end{tabular}

Source: Evaluation Form for the Judges Specialist Committee.

The result of the analysis by each Judge on the quality of translation, adaptation, use of technical terms and preservation of meaning is presented in Table 2 , as well as the maximum possible score and the score observed by the judges' sum of responses in each evaluated aspect.

Table 2 - Evaluation of the Specialist Judges regarding the translation quality of the Questão Chave - São Paulo, São Paulo, Brazil, 2016.

\begin{tabular}{lccccccc}
\hline Judge & J1 & J2 & J3 & J4 & J5 & Maximum score & Obtained score \\
\hline Translation & 3 & 2 & 3 & 3 & 3 & 15 & 14 \\
Adaptation & 2 & 3 & 3 & 3 & 3 & 15 & 14 \\
Technical & 3 & 3 & 3 & 3 & 3 & 15 & 15 \\
terms & & 2 & 3 & 3 & 3 & 15 & 14 \\
Meaning & 3 & 2 & &
\end{tabular}

Source: Evaluation Form for the Judges Specialist Committee.

The CVI for clarity according to the formula used reached $100 \%$ agreement (5/5), which shows that the sentence is clear and without doubts in the opinion of the judges, therefore it shows perfect agreement. Similar results 
were obtained for the translation quality, adaptation and preservation of the original meaning, and the observed CVI was $80 \%(4 / 5)$. There was $100 \%$ (5/5) agreement between the judges regarding the correct use of technical terms.

The index obtained by the Kappa test was 0.83 , which suggests optimal agreement, and very close to the ideal which would be 1 , thus indicating that the agreement between the judges did not happen by chance and that it was in fact related to the translation quality.

$$
\mathrm{K}=\frac{17-2.85}{20-2.85}=0.83
$$

At the end of the content analysis for the Questão chave translated and culturally adapted to Portuguese, we reached the final version of: "Quantas vezes nos últimos 12 meses você bebeu X (5 se for homem ou 4 se for mulher) ou mais doses de bebida alcoólica em um dia?"

The next phase consisted of the pre-test, evaluating the reaction and comprehension level of the S3 version of the Questão Chave by 30 subjects. This was favorable, as there were no discrepancies in understanding between the participants in this stage.

\section{DISCUSSION}

The Questão Chave adapted from its original English version, the Single-Question, followed all the methodological procedures recommended by the literature for instrument adaptation $^{(20-23)}$.

During the adaptation process it was necessary to replace the term "ano passado" for its equivalent "últimos 12 meses" to facilitate understanding of the population in considering the current year to respond to the Questão Chave, which culminated in the $\mathrm{S} 2$ version from the $\mathrm{S} 1$ version. This change was justified by the Judges Committee and accepted by its members.
During the evaluation of the Questão Chave by the Judges Committee, one of the judges suggested that the verb ingerir should be replaced by the verb beber in order to facilitate understanding by a population with a lower education level, and which was promptly accepted by the authors, thus resulting in version $\mathrm{S} 3$.

As presented in the results, the pre-final version of the Questão Chave reached valid and satisfactory Content Validity Indexes according to the literature ${ }^{(24)}$. Regarding the aspect of clarity, the judges were in agreement for all CVI. Regarding the other items, the CVI was close to unanimous agreement, indicating that the Questão Chave was appropriately adapted to the Brazilian culture and was able to be tested for concurrent validation.

There were no major changes suggested by the judges regarding the Questão Chave, only the substitution of one word for another to make it easier to understand. The results obtained using the Kappa index suggest that there was a good agreement between the judges and that this did not happen by chance ${ }^{(24)}$.

The Questão Chave did not generate doubts or dubious interpretations in the pre-test stage among the group of people who use the PHC service, which shows that it was understandable for this population.

\section{CONCLUSION}

The international parameters for translation, adaptation and validation of instruments followed in this study suggest that the Questão Chave is considered valid regarding its content in its Brazilian Portuguese version. Future studies should be focused on testing its concurrent and constructive validity, which presupposes its application in the target population, and the analysis of its psychometric qualities.

\section{RESUMO}

Objetivo: Descrever as etapas de tradução, adaptação cultural e validação de conteúdo da Single-Question para o idioma Português do Brasil, que será denominada de Questão Chave. Método: Estudo de adaptação cultural. O instrumento foi traduzido para o português em duas versões independentes que deram origem à síntese das traduções (S1) e, posteriormente, à síntese S2, que foi submetida à avaliação por um Comitê de Juízes Especialistas na área de álcool e validação de instrumentos. Desta avaliação, calcularam-se o Índice de Validade de Conteúdo e o coeficiente de concordância de Kappa. Resultados: Os Juízes avaliaram a Questão Chave quanto à clareza da sentença e aos aspectos referentes à qualidade da tradução (adaptação cultural, preservação do sentido original e emprego correto de termos técnicos). O Índice de Validade de Conteúdo foi de 1 para clareza da sentença e uso correto de termos técnicos e de 0,8 para adaptação e preservação do sentido original. O Índice de Kappa para concordância entre os juízes foi de 0,83. Após ajuste sugerido pelos juízes, originou-se a versão S3. Conclusão: A Questão Chave teve validade de conteúdo confirmada, o que subsidia estudos futuros que visem sua aplicação na população alvo para verificar suas propriedades psicométricas.

\section{DESCRITORES}

Transtornos Relacionados ao Uso de Álcool; Comparação Transcultural; Estudos de Validação; Reprodutibilidade dos Testes.

\section{RESUMEN}

Objetivo: Describir las etapas de traducción, adaptación cultural y validación de contenido de la Single-Question para el idioma Portugués de Brasil, que será denominada en portugués "Questão Chave" (Cuestión Clave). Método: Estudio de adaptación cultural. $\mathrm{El}$ instrumento fue traducido al portugués en dos versiones independientes que dieron origen a la síntesis de las traducciones (S1) y, posteriormente, a la síntesis S2, que fue sometida a la evaluación por un Comité de Jueces Expertos en el área de alcohol y validación de instrumentos. Mediante dicha evaluación, se calcularon el Índice de Validez de Contenido y el coeficiente de concordancia de Kappa. Resultados: Los Jueces evaluaron la Cuestión Clave en cuanto a la claridad de la sentencia y los aspectos referentes a la calidad de la traducción (adaptación cultural, preservación del sentido original y empleo correcto de términos técnicos). El Índice de Validez de Contenido fue de 1 para claridad de la sentencia y uso correcto de términos técnicos y de 0,8 para adaptación y preservación del sentido 
original. E1 Índice de Kappa para concordancia entre los jueces fue de 0,83. Después del ajuste sugerido por los jueces, se originó la versión S3. Conclusión: La Cuestión Clave tuvo validez de contenido confirmada, lo que subsidia estudios futuros que tengan como meta su aplicación en la población blanco a fin de verificar sus propiedades psicométricas.

\section{DESCRIPTORES}

Transtornos Relacionados con Alcohol; Comparación Transcultural. Estudios de Validación; Reproducibilidad de Resultados.

\section{REFERENCES}

1. World Health Organization. Strategies to reduce the harmful use of alcohol [Internet]. Geneva: WHO; 2008 [cited 2016 Aug 20 ]. Available from: http://www.who.int/substance_abuse/activities/gsrhua/en/

2. Garcia LP, Freitas LRS. Consumo abusivo de álcool no Brasil: resultados da Pesquisa Nacional de Saúde 2013. Epidemiol Serv Saúde. $2015 ; 24(2): 227-37$.

3. World Health Organization. Global status report on alcohol and health [Internet]. Geneva: WHO; 2014 [cited 2016 Aug 20]. Available from: http://apps.who.int/iris/bitstream/10665/112736/1/9789240692763_eng.pdf

4. Galassi AD, Alvarenga PG, Andrade AG, Couttolenc BF. Custos dos problemas causados pelo abuso do álcool. Rev Psiq Clín. 2008;35(1):25-30.

5. Jomar RT, Abreu AMM, Griep RH. Patterns of alcohol consumption and associated factors among adult users of primary health care services of Rio de Janeiro, Brazil. Ciênc Saúde Coletiva. 2014;19(1):27-38.

6. Ronzani TM, Mota DCB, Souza CW. Prevenção do uso de álcool na atenção primária em municípios do estado de Minas Gerais. Rev Saúde Pública. 2009;43(1):51-61.

7. Smith PC, Smith SM, Davies-Allensworth D, Saitz R. Primary care validation of a single-question alcohol screening test. J Gen Intern Med. 2009;24(7):783-8.

8. Mansur J, Monteiro MG. Validation of the CAGE alcoholism screenig test in a Brazilian psychiatric inpatient hospital setting. Braz J Med Biol Res. 1983;16(3):215-8.

9. Figlie NB, Pillon SC, Laranjeira R., Dunn J. O AUDIT identifica a necessidade de interconsulta específica para dependentes de álcool no hospital geral? J Bras Psiq. 1997; 41(11):589-93.

10. Santos WS, Gouveia VV, Fernandes DP, Souza SSB, Grangeiro ASM. Alcohol Use Disorder Identification Test (AUDIT): explorando seus parâmetros psicométricos. J Bras Psiq. 2012;61(3):117-23.

11. Fabri CE, Furtado EF, Laprega MR. Alcohol consumption in pregnancy: performance of the Brazilian version of the questionnaire T-ACE. Rev Saúde Pública. 2007;41(6):979-84.

12. Meneses-Gaya C, Crippa JAS, Zuardi AW, Loureiro SR, Hallak JE, Trzesniak C, et al. The fast alcohol screening test (FAST) is as good as the AUDIT to screen alcohol use disorders. Subst Use Misuse. 2010;45(10):1542-57.

13. Kano MY, Santos MA, Pillon SC. Use of alcohol in the elderly: transcultural validation of the Michigan Alcoholism Screening Test - Geriatric Version (MAST-G). Rev Esc Enferm USP [Internet] . 2014 [cited 2016 Aug 20];48(4 ):648-56. Available from: http://www.scielo.br/pdf/reeusp/v48n4/0080-6234-reeusp-48-04-648.pdf

14. National Institute on Alcohol Abuse and Alcoholism. Helping patient who drinks too much: a clinician's guide. Whashigton: NIAAA; 2005.

15. Fleming MF, Barry KL, Manwell LB, Jhon K, London R. Brief physician advice for problem alcohol drinkers: a randomized controlled trial in community-based primary care practices. JAMA. 1997;277(13):1039-45.

16. Taj N, Devera-Sales A, Vinson DC. Screening for problem drinking: does a single question work ? J Fam Pract. 1998;46(4):328-35.

17. Williams R, Vinson DC. Validation of a single screening question for problem drinking. J Fam Pract. 2001;50(4):307-12.

18. Agabio R, Gessa GL, Montisci A, Finco G, Contu P, Bedogni G, et al. Use for the screening suggested by the National Institute on Alcohol Abuse and Alcoholism and of newly derived tool for the detection of unhealthy alcohol drinkers among surgical patients. J Stud Alcohol Drugs. 2012;73(1):126-33.

19. Jomar RT, Paixão LAR, Abreu AMM. Alcohol Use Disorders Identification Test (AUDIT). Rev APS. 2012;15(1):113-7.

20. Polit DF, Beck CT. Fundamentos da pesquisa em enfermagem: métodos, avaliação e utilização. $7^{a}$ ed. Porto Alegre: Artes Médicas; 2011.

21. Beaton DE, Bombardier C, Guillemin F, Ferraz MB. Guidelines for the process of cross-cultural adaptation of self-report measures. Spine. 2000;25(24):3186-91.

22. Cunha CM, Almeida Neto OP, Stackfleth R. Principais métodos de avaliação psicométrica de validade de instrumentos de medida. Rev Atenção Saúde. 2016;14(47):75-83.

23. Alexandre NMC, Coluci MZO. Content validity in the development and adaptation processes of measurement instruments. Ciênc Saúde Coletiva. 2011;16(7):3061-8.

24. Pasquali L. Instrumentação psicológica: fundamentos e práticas. Porto Alegre: Artmed; 2010.

25. Formiga NS. Identificação dos problemas relacionados ao uso de álcool no final de semana: proposta de uma escala de medida em universitários. Encontro Rev Psicol [Internet]. 2014 [citado 2016 ago. 20];17(26):85-97. Disponível em: http://www.pgsskroton.com.br/seer/index.php/renc/article/view/2418 